\title{
Suppressive Effect of Silicon Nutrient on Phomopsis Stem Blight Development in Asparagus
}

\author{
Gang Lu', Wenlei Jian, Jiajing Zhang, Yijing Zhou, and Jiashu Cao
} Key Laboratory of Horticultural Plant Growth, Development and Biotechnology, Ministry of Agriculture, Department of Horticulture, 268 Kuaixuan Road, Zhejiang University, Hangzhou, 310029, P.R. China

Additional index words. Asparagus officinalis L., antioxidant enzymes, silicon content, induced resistance, Phomopsis asparagi

\begin{abstract}
The effects of silicon nutrition on the resistance to stem blight caused by Phomopsis asparagi was assessed in two asparagus cultivars, UC157 and Gynlim, and the activation of defense responses in inoculated plants was measured in a greenhouse with nutrient solution culture. The supply of silicon ( $\mathrm{Si}$ ) significantly suppressed stem blight development in inoculated plants. The disease index was significantly reduced in $\mathrm{Si}$ supplied plants compared with Si-deprived plants in both cultivars. Supplement with Si enhanced $\mathrm{Si}$ accumulation in asparagus root and shoot. Si content was significantly higher in Si-treated plants when compared with control plants, but it was not significantly different between the two cultivars. Interestingly, inoculation with $P$. asparagi increased $\mathrm{Si}$ content in shoots in the cultivar UC157. Root-applied Si significantly enhanced the activities of pathogenesis-related proteins (PRs) such as catalase, peroxidase, polyphenoloxidase, and $\beta-1,3$-glucanase in inoculated plants. However, Si treatment mostly failed to change significantly the activity of PRs in plants without fungal attack. So continuous feeding of Si to the plant is probably important for enhancing the resistance to infection by $P$. asparagi in asparagus.
\end{abstract}

Asparagus officinalis L., a member of the family Liliaceae, is an important vegetable worldwide for its culinary and medicinal properties. The world total yield reached $6,346,000 \mathrm{t}$ in 2006 (FAO, 2006). Stem blight, caused by a complex of fungal species such as Phoma or Phomopsis asparagi (Sacc.) Bubák, is an important constraint for asparagus production. The disease causes cladodes to turn yellow and later brown with complete desiccation and stem death. It is a destructive disease of asparagus reported in many parts of the world such as the United States, China, Japan, France, Germany, Brazil, and Peru, particularly in humid areas (Davis, 2001; Elena, 2006; Reifschneider and Lopes, 1982).

Control of Phomopsis is very difficult as a result of its survival capacity in various environments. Despite many years of breeding efforts, no resistant or tolerant cultivars have yet been developed. Sonoda et al. (1997) evaluated 24 cultivars and two lines for the resistance to asparagus stem blight caused by $P$. asparagi under controlled envi-

\footnotetext{
Received for publication 20 Nov. 2007. Accepted for publication $5 \mathrm{Feb} .2008$.

This work was funded by the Zhejiang Provincial Key Subject, China (2005C32013).

We thank Prof. Zhang Jianzhe from the Department of Phytopathology for his help in obtaining the pathogen isolates. We also thank Prof. Hu Jin for his help in analyzing the data.

${ }^{1}$ To whom reprint requests should be addressed; e-mail glu@zju.edu.cn
}

ronmental conditions and found that none of the cultivars or lines showed high resistance. Therefore, only integrated control consisting of cultural and biological methods seems promising for asparagus production.

Although silicon ( $\mathrm{Si}$ ) is not defined as an essential element in classical parlance, $\mathrm{Si}$ is actively involved in metabolic or physiological activities, especially in plants subject to multiple stresses. Suppressive effects of $\mathrm{Si}$ against plant pathogens in soil culture have been known since the 1920s (Kawashima, 1927). In recent years, there is ample literature linking the presence of Si with resistance of plants against fungal pathogens such as Pythium ultimum (Chérif et al., 1992, 1994) and Sphaerotheca fuliginea (Fawe et al., 1998) in cucumber, Magnaporthe grisea and Thanatephorus cucumeris (Rodrigues et al., 2001, 2005) in rice, and powdery mildews in barley (Carver et al., 1987), wheat (Bélanger et al., 2003; Rémus-Borel et al., 2005), and strawberry (Kanto et al., 2006).

The mechanism involved in Si-induced resistance of plants to fungal diseases is not yet fully understood (Epstein, 1994). Some authors suggested that $\mathrm{Si}$ acted as a physical or mechanical barrier in plants (Bowen et al., 1992; Carver et al., 1987; Samuels et al., 1993), whereas others believed Si was related to specific plant defense reactions (Bélanger et al., 2003; Chérif et al., 1994; Fawe et al., 1998; Rodrigues et al., 2004). There was strong evidence indicating that the mechanism might be prophylactic through enhancement of the natural defense systems through the production of phenolic compounds (Fawe et al., 1998; Rodrigues et al., 2003) or the activation of defense-related enzymes such as peroxidase (POD), polyphenoloxidases (PPO), chitinases, and $\beta$-1, 3-glucanase (Chérif et al., 1994; Dann and Muir, 2002; Rodrigues et al., 2005). Further studies showed that the epidermal cells of Si-treated plants reacted to fungus attack with specific defense reactions, including papilla formation, production of cellulose, and release of glycosylated phenolics (Bélanger et al., 2003; Rodrigues et al., 2004). More recently, Rodrigues et al. (2004) and Rémus-Borel et al. (2005) confirmed that rice and wheat plants fed with Si could produce phytoalexins in response to blast and powdery mildew infection, respectively. So the mechanism of Si-mediated resistance to fungal attacks in plants appears to be extremely complicated depending on the fungus plant pathogen involved and many other unknown factors (Fauteux et al., 2005; Ma, 2004; Ma and Yamaji, 2006).

The objectives of this study were to investigate the effects of supplement with $\mathrm{Si}$ in the nutrient solution on induction of the resistance to $P$. asparagi in asparagus and to examine the defense mechanisms such as activation of defense-related pathogenesisrelated proteins (PRs) involved in antioxidant system and phenolic metabolism. Insight into the protective roles of $\mathrm{Si}$ in response to fungal attack will lead to improved strategies for disease control by exploitation of induced pathogen resistance in asparagus.

\section{Materials and Methods}

Plant materials and culture. Asparagus cultivars 'UC157' $\mathrm{F}_{1}$, susceptible to P. asparagi, and 'Gynlim', partially resistant to Phomopsis stem blight (Sonoda et al., 1997), were provided by Zhejiang Seed Company, China. Asparagus seeds were first surfacedisinfected in $1.5 \%$ sodium hypochlorite for $30 \mathrm{~min}$ and subsequently dipped in a mixture of benomyl and acetone ( $2.5 \mathrm{~g}$ benomyl/100 $\mathrm{mL}$ acetone) for $24 \mathrm{~h}$ and then rinsing them in acetone $(3 \times)$ and distilled water $(3 \times)$. They were germinated aseptically in $9-\mathrm{cm}$ petri plates on moistened sterile filter paper at $25^{\circ} \mathrm{C}$ in the dark for 1 week, sowed in vermiculite media, and grown in a glasshouse at Zhejiang University farm at $25^{\circ} \mathrm{C}$ day $/ 20^{\circ} \mathrm{C}$ night in the fall of 2006 . The vermiculite was soaked in dilute $\mathrm{HCl}$ solution for $24 \mathrm{~h}$ for sterilization, then washed repeatedly with distilled water, and dried in an oven at $55^{\circ} \mathrm{C}$ before use.

Ten days after germination, the seedlings were transferred to black plastic containers containing $8 \mathrm{~L}$ hydroponic solution $(\mathrm{pH}=$ 6.2): $5.0 \mathrm{mmol} \cdot \mathrm{L}^{-1} \mathrm{Ca}\left(\mathrm{NO}_{3}\right)_{2}, 4.0 \mathrm{mmol} \cdot \mathrm{L}^{-1}$ $\mathrm{KNO}_{3}, 1.0 \mathrm{mmol} \cdot \mathrm{L}^{-1} \mathrm{KH}_{2} \mathrm{PO}_{4}, 2.0 \mathrm{mmol} \cdot \mathrm{L}^{-1}$ $\mathrm{MgSO}_{4}, \quad 70.0 \mu \mathrm{mol} \cdot \mathrm{L}^{-1}$ Fe-EDTA, 10.0 $\mu \mathrm{mol} \cdot \mathrm{L}^{-1} \quad \mathrm{MnSO}_{4}, \quad 50.0 \mu \mathrm{mol} \cdot \mathrm{L}^{-1} \mathrm{H}_{3} \mathrm{BO}_{3}$, $0.7 \mu \mathrm{mol} \cdot \mathrm{L}^{-1} \mathrm{ZnSO}_{4}, 0.2 \mu \mathrm{mol} \cdot \mathrm{L}^{-1} \mathrm{CuSO}_{4}$, $0.01 \mu \mathrm{mol} \cdot \mathrm{L}^{-1}\left(\mathrm{NH}_{4}\right)_{6} \mathrm{Mo}_{7} \mathrm{O}_{24}$. Distilled water was used for the nutrient solution. The hydroponic solution was aerated through a tube system connected to a pump and renewed every $4 \mathrm{~d}$. Plants were grown under 
controlled condition with a temperature of $23 \pm$ $2{ }^{\circ} \mathrm{C}$ day $/ 15 \pm 2{ }^{\circ} \mathrm{C}$ night and a photoperiod of $13 \mathrm{~h}$ and light intensity of $350 \mu \mathrm{mol} \cdot \mathrm{m}^{-2} \cdot \mathrm{s}^{-1}$. Asparagus seedlings were grown in nutrient solution for 8 weeks before inoculation.

Fungal isolates. Fungal isolates were obtained on PDA medium from blighted asparagus stem collected in fields at Zhejiang University farm in the spring of 2006. Based on the morphological characteristics, the fungus was identified as $P$. asparagi (Uecker and Johnson, 1991). Pathogenicity test proved that the symptoms appearing in inoculated stems and leaves in 4-week seedlings were identical to the symptoms observed on young infections in the field (data not shown).

Fungal conidia were harvested from 2week-old culture in PDA at 20 to $23{ }^{\circ} \mathrm{C}$ by dislodging the spores with a glass rod into distilled water. Spore suspensions were filtered through cheesecloth to remove mycelium and agar chunks, the filtrate was centrifuged at $6000 \times g$ for $5 \mathrm{~min}$, and the spore pellet was resuspended in distilled water. One drop of Tween-20 was added to each $500 \mathrm{~mL}$ distilled water. The concentration for plant inoculation was adjusted to $1 \times$ $10^{6}$ spores $/ \mathrm{mL}$.

In vitro test. In vitro test against $P$. asparagi was conducted according to the method of El-Ghaouth et al. (1992). Sodium chloride or sodium silicate $\left(\mathrm{Na}_{2} \mathrm{SiO}_{3} \cdot 9 \mathrm{H}_{2} \mathrm{O}\right)$ was added to autoclaved PDA medium to provide final concentrations of $0,3,6,9$, and $12 \mathrm{mmol} \cdot \mathrm{L}^{-1}$. The amended plates received in the center agar plugs ( $6 \mathrm{~mm}$ in diameter) cut from the edge of actively growing colonies of $P$. asparagi on PDA, and then they were incubated at $25 \pm 0.5{ }^{\circ} \mathrm{C}$ in the dark. The diameters of the fungal growth were measured every $24 \mathrm{~h}$. Incubation of the plates stopped when pathogen growth covered the entire petri plate of the control. Nine replicates were used for each concentration and the control and the entire experiment was repeated four times in the same condition.

Inoculation. Absorbent cotton $(10 \times 10$ $\mathrm{mm}$ ) was placed around the stem of young asparagus plants cultivated in the nutrient solution supplied with or without $\mathrm{Si}$ and then covered with a chlorinated vinyl tube (slit lengthwise) to maintain the cotton at the site of inoculation. Then $0.6 \mathrm{~mL}$ of a spore suspension $\left(1 \times 10^{6}\right.$ conidia $\left./ \mathrm{mL}\right)$ was infiltrated with a micropipette into the cotton. Control plants were sprayed with sterile water. The inoculated and control plants were covered with polyethylene films for $48 \mathrm{~h}$ to keep the air humidified around the young seedlings, and they were kept in the greenhouse.

Treatments. A $2 \times 2 \times 2$ factorial experiment consisting of two levels of $\mathrm{Si}$, two genotypes, and inoculated or noninoculated treatments was arranged in a completely randomized design including 1) control plants without $\mathrm{Si}$ and $P$. asparagi inoculation $(-\mathrm{Si}-\mathrm{Pa}) ; 2)$ plants without $\mathrm{Si}$, inoculated with $P$. asparagi $(-\mathrm{Si}+\mathrm{Pa}) ; 3)$ plants with $\mathrm{Si}$, without $P$. asparagi inoculation $(+\mathrm{Si}-\mathrm{Pa})$; and 4) plants with $\mathrm{Si}$, inoculated with $P$. asparagi $(+\mathrm{Si}+\mathrm{Pa})$. In those $\mathrm{Si}-$ supplied treatments, $1.5 \mathrm{mmol} \cdot \mathrm{L}^{-1} \quad \mathrm{Na}_{2} \mathrm{SiO}_{3} \cdot 9 \mathrm{H}_{2} \mathrm{O}$ was added to the nutrient solution, meanwhile control plants were treated with an equivalent amount of $\mathrm{NaCl}$. Each treatment had three replications under the controlled greenhouse condition and each replicate included 24 plants.

After 1 week of the Si addition in nutrient solution, seedling was inoculated with $P$. asparagi. The disease evaluation began at $1 \mathrm{~d}$ after inoculation and continued every $3 \mathrm{~d}$ up to $13 \mathrm{~d}$, when most of plants died in some treatments. Ten plants per treatment were evaluated for disease severity and visually rated on a 1 to 5 scale: $1=$ no symptoms or lesions; 2 = have some small noncoalesced lesions, presenting on $1 \%$ to $25 \%$ of stem; $3=$ lesions present on $26 \%$ to $50 \%$ of stem, or coalesced lesions, no girdling; $4=51 \%$ to $75 \%$ of stem coalesced lesions, girdling; $5=$ $76 \%$ or greater of stem covered with lesions, withered and dead stem.

From disease severity ratings, percent disease index (PDI) was calculated using the following formula and analysis of variance for PDI values at different days postinoculation (dpi) was also calculated.

PDI (percent disease index $)=$

sum of scales of all observations

number of observations $x$ $\times 100$

maximum scale value

Silicon quantification. Five randomly chosen plants per replicate were harvested at $13 \mathrm{dpi}$ and separated into the shoot and root. The shoots and roots were washed once with tap water and soaked in $0.5 \mathrm{M} \mathrm{HCl}$ for $15 \mathrm{~s}$ followed by four rinses in distilled water. After weighing fresh weights, Si content in each of these treatments was determined as previously reported by $\mathrm{Lu}$ (2001) and Taber et al. (2002). The samples were air-dried at $67{ }^{\circ} \mathrm{C}$ and ground to pass a 60 mesh screen. After thorough mixing, a subsample of $200 \mathrm{mg}$ was placed in a $100-\mathrm{mL}$ polyethylene bottle and digested with $\mathrm{HCl}-\mathrm{HF}$ solution $(10 \mathrm{~mL}$ of $1 \mathrm{M} \mathrm{HCl}$ plus $20 \mathrm{~mL}$ of $2.3 \mathrm{M}$ $\mathrm{HF}$ ) overnight. After filtering, the extract was detected for Si content with an inductively coupled agron plasma (ICAP) procedure. The instrument was an ICAP/IRIS (Thermo Elemental Corp., Franklin, MA) dual-view, charge-injection device fitted with a HF resistant torch, spray chamber, and nebulizer assembly. The operational settings were radiofrequency power $1100 \mathrm{~W}$, nebulizer flow rate $2.035 \mathrm{~mL} \cdot \mathrm{min}^{-1}$, pump speed 110 $\mathrm{rpm}$, equilibration time $15 \mathrm{~s}$, and the wavelength selected was $250.69 \mathrm{~nm}$. A linear curve was established with $0,10,20,30$, 40 , and $50 \mathrm{mg} \cdot \mathrm{L}^{-1} \mathrm{Si}$ standards $(\mathrm{r}=0.99997)$.

Enzyme assays. The susceptible cultivar UC157 $F_{1}$ was used for enzyme analysis in the following experiment. The stem tissues were sampled at $1,4,7,10$, and $13 \mathrm{dpi}$ and frozen with liquid nitrate, stored at $-75^{\circ} \mathrm{C}$ until assay.

For enzyme analysis, $0.5 \mathrm{~g}$ of fresh asparagus samples were homogenized in an ice bath in $5 \mathrm{~mL}$ of a $25 \mathrm{mmol} \cdot \mathrm{L}^{-1}$ HEPES buffer (contained $0.2 \mathrm{mmol} \cdot \mathrm{L}^{-1}$ EDTA, $\mathrm{pH}$ 7.8 ) and $2 \%$ polyvinylpyrrolidone. The homogenate was centrifuged at $13,000 \mathrm{~g}$ for $20 \mathrm{~min}$ at $4{ }^{\circ} \mathrm{C}$. The supernatant was used a crude enzyme extract in superoxide dismutase (SOD), catalase (CAT), POD, PPO, and dehydroascorbate reductase (DHAR) enzyme analyses. All assays were conducted in an ultraviolet/visible light spectrophotometer (Shimadzu ultraviolet-2410 PC, Shimadzu, Kyoto, Japan). Four separate extractions were performed for each treatment for assay of the activities of all enzymes.

Superoxide dismutase activity assay was based on the method described by Giannopolitis and Ries (1977). One unit of SOD (U) was defined as the amount of enzyme that produced a $50 \%$ inhibition of the rate of nitroblue tetrazolium reduction measured at $560 \mathrm{~nm}$

Catalase activity was measured by the decline in absorbance at $240 \mathrm{~nm}$ resulting from the decline of extinction of $\mathrm{H}_{2} \mathrm{O}_{2}$ (Cakmak and Marschner, 1992). The reaction mixture contained $25 \mathrm{~mm}$ sodium phosphate buffer ( $\mathrm{pH} 7.0$ ), $10 \mathrm{~mm} \mathrm{H}_{2} \mathrm{O}_{2}$, and $0.1 \mathrm{~mL}$ enzyme extracts. The reaction was initiated by the addition of $100 \mu \mathrm{L}$ of enzyme extract and activity was determined by measuring the initial rate of disappearance of $\mathrm{H}_{2} \mathrm{O}_{2}$.

Peroxidase activity was assayed following the method of Zhu et al. (1998). The assay medium contained $50 \mathrm{~mm}$ phosphate buffer (pH 5.8), $7.2 \mathrm{~mm}$ guaiacol, $11.8 \mathrm{mM} \mathrm{H}_{2} \mathrm{O}_{2}$, and $0.1 \mathrm{~mL}$ enzyme extract in a final assay volume of $3.0 \mathrm{~mL}$. The reaction was initiated by the addition of $\mathrm{H}_{2} \mathrm{O}_{2}$ and the change in absorbance at $470 \mathrm{~nm}$ was measured.

Dehydroascorbate reductase activity was carried out by measuring the increase in absorbance at $265 \mathrm{~nm}$ resulting from reduced ascorbate formation (Nakano and Asada, 1981). The reaction system included $50 \mu \mathrm{L}$ extract, $25 \mathrm{mmol} \cdot \mathrm{L}^{-1}$ sodium phosphate buffer (containing $0.1 \mathrm{mmol} \cdot \mathrm{L}^{-1}$ EDTA, $\mathrm{pH}$ 7.0), $3.5 \mathrm{mmol} \cdot \mathrm{L}^{-1}$ deoxidized glutathione, and $0.4 \mathrm{mmol} \cdot \mathrm{L}^{-1}$ dehydroascorate.

Polyphenoloxidases activity was assayed following the method of Rivas and Whitaker (1973) with minor modifications. The reaction was started by adding $0.1 \mathrm{~mL}$ enzyme extract to a mixture containing $4.4 \mathrm{~mL} 50$ $\mathrm{mmol} \cdot \mathrm{L}^{-1}$ potassium phosphate buffer $(\mathrm{pH}$ 6.8 ) and $0.5 \mathrm{~mL} 0.15 \mathrm{mmol} \cdot \mathrm{L}^{-1}$ catechol. The reaction was ended by adding $0.5 \mathrm{~mL} 15 \%$ $\mathrm{H}_{2} \mathrm{SO}_{4}$ after incubated at $25{ }^{\circ} \mathrm{C}$ for $5 \mathrm{~min}$. Absorbance was recorded at $420 \mathrm{~nm}$ for $10 \mathrm{~min}$.

For assaying phenylalanine ammonialyase (PAL) activity, $1.0 \mathrm{~g}$ fresh asparagus segments (less than $2 \mathrm{~mm}$ ) was homogenized in an ice bath in $5 \mathrm{~mL}$ of a $50 \mathrm{mmol} \cdot \mathrm{L}^{-1}$ borate buffer ( $\mathrm{pH} 8.8$ ) containing $5.0 \mathrm{mmol} \cdot \mathrm{L}^{-1}$ thioalcohol and $1 \mathrm{mmol} \cdot \mathrm{L}^{-1}$ EDTA. The homogenate was centrifuged at $9000 \mathrm{~g}$ for 25 min at $4{ }^{\circ} \mathrm{C}$. A reaction mixture containing $3.8 \mathrm{~mL} 50 \mathrm{mmol} \cdot \mathrm{L}^{-1}$ borate buffer $(\mathrm{pH} 8.8)$ and $1.0 \mathrm{~mL} \quad 0.6 \mathrm{mmol} \cdot \mathrm{L}^{-1} \mathrm{~L}$-phenylalanine was added to $0.2 \mathrm{~mL}$ of the crude enzyme extract. After incubation for $60 \mathrm{~min}$ at $60^{\circ} \mathrm{C}$, 
the reaction was stopped by adding $0.2 \mathrm{~mL}$ $6 \mathrm{~mol} \cdot \mathrm{L}^{-1} \mathrm{HCl}$. The absorbance was recorded at $290 \mathrm{~nm}$.

For assaying glucanase, $0.4 \mathrm{~g}$ fresh samples were homogenized in an ice bath in a buffer consisting of $2 \mathrm{~mL} 50 \mathrm{mmol} \cdot \mathrm{L}^{-1}$ sodium acetate ( $\mathrm{pH} 5.0)$ and 0.05 g polyvinylpyrrolidone and then centrifuged at $10,000 \mathrm{~g}$ for $30 \mathrm{~min}$ at $4{ }^{\circ} \mathrm{C}$. The supernatant was designated as a crude extract. The laminarin was used as a substrate, and 0.2 $\mathrm{mL}$ of extract was routinely added to $0.4 \mathrm{~mL}$ $0.1 \%$ (w/v) laminarin (Sigma, St. Louis, MO) in preheated water and incubated at $37^{\circ} \mathrm{C}$ for $30 \mathrm{~min}$; the reaction was stopped by adding 3 $\mathrm{mL}$ of the dinitrosalicylic reagent and heating the tubes for $5 \mathrm{~min}$ at $100{ }^{\circ} \mathrm{C}$. The contents were diluted 1:10 with water and detected at $540 \mathrm{~nm}$. One unit of activity was defined as the amount of enzyme producing 1 $\mathrm{mmol} \cdot \mathrm{min}^{-1}$ of glucose equivalents at $37^{\circ} \mathrm{C}$.

For assaying chitinase activity, $1.0 \mathrm{~g}$ fresh sample was homogenized in an ice bath in a buffer consisting of $5 \mathrm{~mL} 100 \mathrm{mmol} \cdot \mathrm{L}^{-1}$ acetate buffer ( $\mathrm{pH} 5.0)$ containing $1 \%(\mathrm{w} / \mathrm{v})$ ascorbic acid and $1 \%(\mathrm{w} / \mathrm{v})$ polyvinylpyrrolidone. After centrifugation at $10,000 \mathrm{~g}$ for $30 \mathrm{~min}$, the supernatant was designated as a crude extract. A reaction mixture containing $3.8 \mathrm{~mL} 50 \mathrm{mmol} \cdot \mathrm{L}^{-1}$ acetate buffer (pH 5.0) and $1.0 \mathrm{~mL} 0.05 \%$ deacetyl glycol chitin was added to $0.1 \mathrm{~mL}$ crude enzyme extract. After $30 \mathrm{~min}$ at room temperature, the reaction was ended by heating at $100^{\circ} \mathrm{C}$ for $5 \mathrm{~min}$. The end products released by asparagus chitinase were determined colorimetrically at $585 \mathrm{~nm}$ (Boller and Metraux, 1988). One unit of chitinase activity was defined as the amount of enzyme that liberated $1 \mathrm{~mol} \mathrm{~N}$-acetylglucosamine per hour at $37^{\circ} \mathrm{C}$.

Data analysis. The normal distribution and variance homogeneity for all data were detected and analyzed with SAS software (SAS Institute, 2002). Data were tested for normality by using the Shapiro-Wilk test and were similarly tested for homogeneity of variance by the Bartlett's test using the HOVTEST=BARTLETT option in the procedure of PROC GLM on all dependent variables. Analyses of variance (ANOVAs) were performed with the PROC ANOVA procedure of SAS. Normally distributed data with homogeneous variances were compared using Tukey test at $P<0.05$. The results presented were means \pm SES.

\section{Results}

The growth of $\mathrm{P}$. asparagi in vitro. Sodium silicate significantly inhibited the mycelia growth of $P$. asparagi $(P<0.0001)$ at the concentrations higher than $3 \mathrm{mmol} \cdot \mathrm{L}^{-1}$ compared with the control treatment (Fig. 1). When the $\mathrm{Si}$ concentration increased to 9 $\mathrm{mmol} \cdot \mathrm{L}^{-1}$ or higher, the fungus turned brown and the growth of pathogen was completely suppressed. However, $\mathrm{NaCl}$ in the media had no significant suppressive effect on the growth of $P$. asparagi.

Symptom development in two asparagus cultivars. There was no disease development

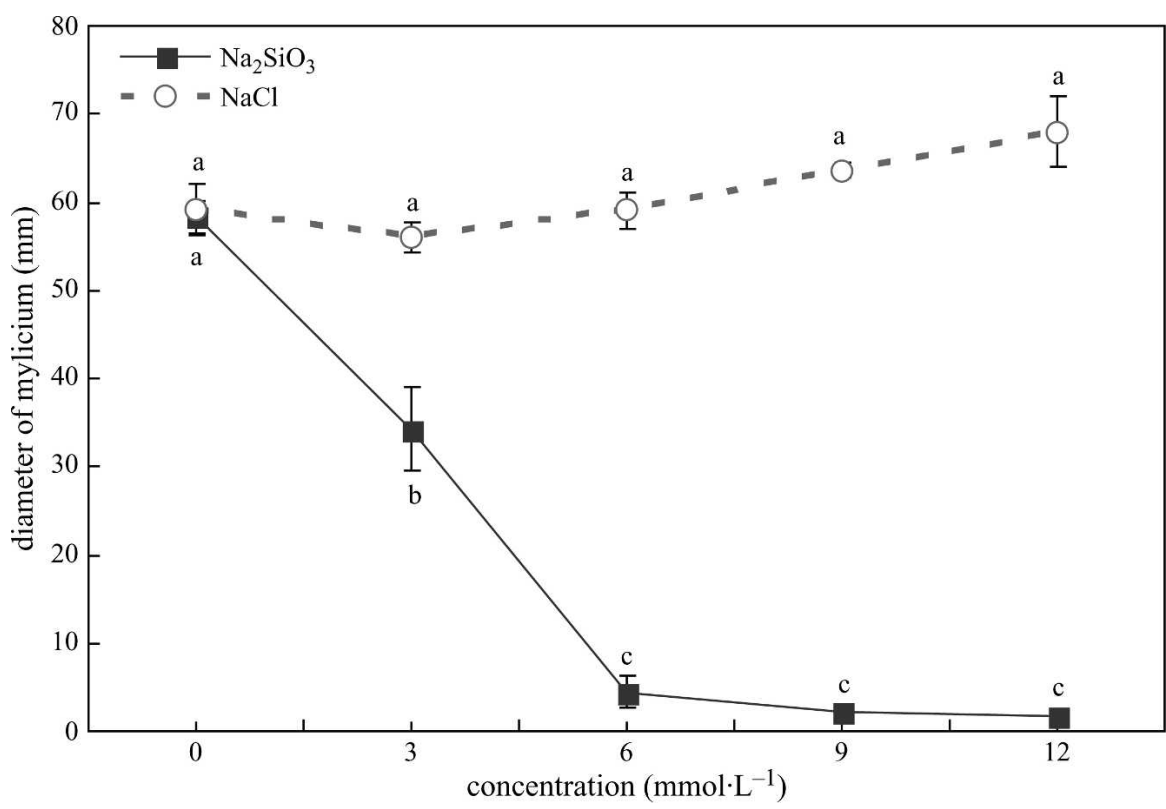

Fig. 1. Effect of $\mathrm{NaCl}$ and $\mathrm{Na}_{2} \mathrm{SiO}_{3}$ in different concentrations on the mycelium growth of Phomopsis asparagi in vitro at $6 \mathrm{~d}$ after inoculation. Data points represent means of four repeated trials $\pm \mathrm{SE}$. Mean separation on line by Tukey's test at $P=0.05$. Different letters in the same line denote significant differences between $\mathrm{NaCl}$ and $\mathrm{Na}_{2} \mathrm{SiO}_{3}$ treatments.

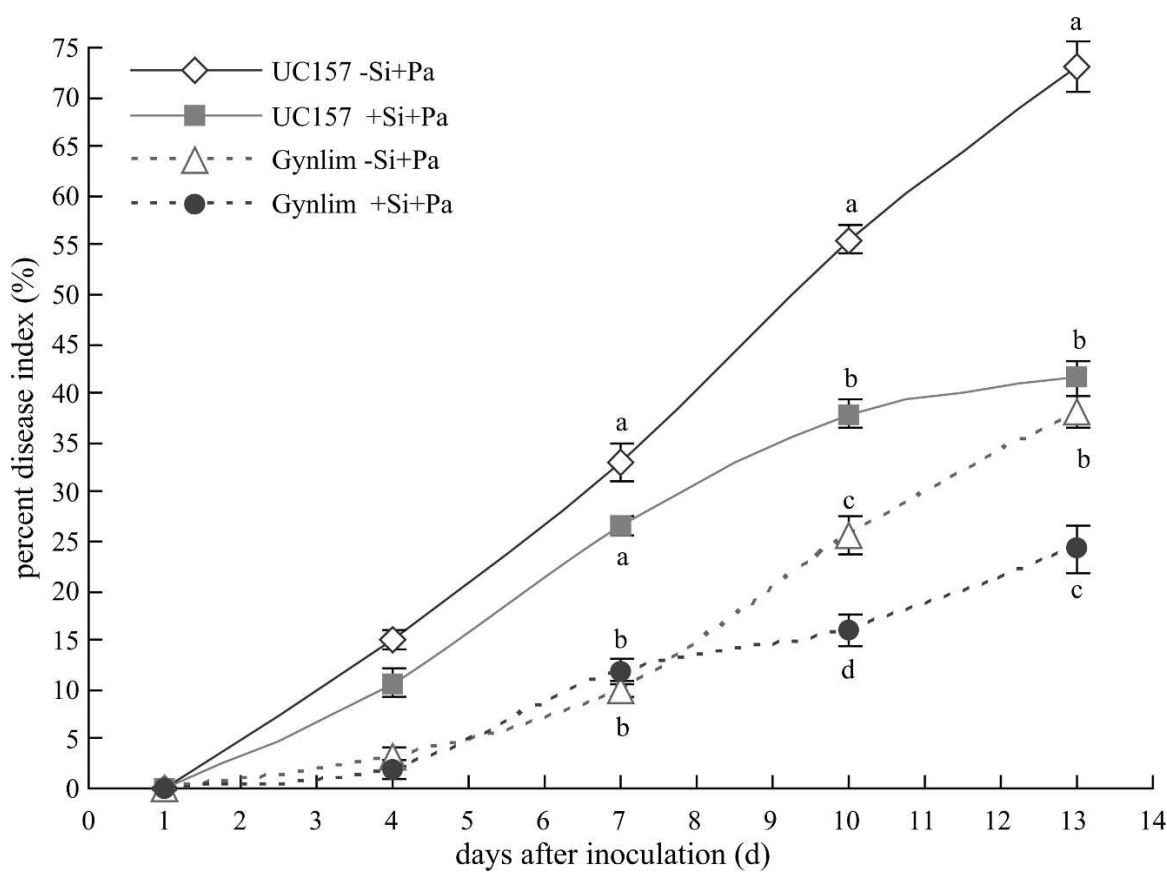

Fig. 2. Effect of silicon on Phomopsis stem blight disease index in asparagus cultivars UC157 and Gynlim grown in nutrient solution culture. Data points represent means of three repeated trials \pm SE. Means separation on each evaluation day (on column) by Tukey's test at $P=0.05$. Different letters in each line represent significant difference between treatments.

Table 1. Silicon concentration (mg. $\mathrm{g}^{-1}$ dry weight) in asparagus cultivars UC157 and Gynlim grown in a nutrient solution without and with silicon $13 \mathrm{~d}$ after inoculation with Phomopsis asparagi.

\begin{tabular}{lccccc}
\hline & \multicolumn{2}{c}{ UC157 } & & \multicolumn{2}{c}{ Gynlim } \\
\cline { 2 - 3 } \cline { 5 - 6 } & Shoot & Root & & Shoot & Root \\
\hline$-\mathrm{Si}-\mathrm{Pa}$ & $0.72 \pm 0.07 \mathrm{aC}$ & $0.55 \pm 0.05 \mathrm{aB}$ & & $0.71 \pm 0.10 \mathrm{aB}$ & $0.67 \pm 0.09 \mathrm{aB}$ \\
$+\mathrm{Si}-\mathrm{Pa}$ & $1.88 \pm 0.07 \mathrm{bB}$ & $4.05 \pm 0.65 \mathrm{aA}$ & & $2.37 \pm 0.33 \mathrm{bA}$ & $5.16 \pm 0.38 \mathrm{aA}$ \\
$+\mathrm{Si}+\mathrm{Pa}$ & $2.65 \pm 0.06 \mathrm{bA}$ & $4.12 \pm 0.54 \mathrm{aA}$ & & $2.72 \pm 0.28 \mathrm{bA}$ & $5.90 \pm 0.36 \mathrm{aA}$ \\
\hline
\end{tabular}

Data points represent means of three repeated trials \pm sEs. Means followed by the same letters are not significantly different with Tukey's test at $P=0.05$. Upper case letters vertically refer to the comparison between treatments for the same organ, and lower case letters horizontally refer to the comparison between plant organs for the same treatments and genotypes. 
in noninoculated plants. When the asparagus seedlings were inoculated with $P$. asparagi, both the cultivar and addition of Si significantly affected the symptom development (Fig. 2). Disease severity was significantly reduced in Si-treated plants compared with plants without $\mathrm{Si}$. In the susceptible cultivar UC157, typical stem symptoms and necrotic lesions were observed at $4 \mathrm{~d}$ after inoculation in Si-deprived plants. The disease index increased sharply with time and reached $73.1 \%$ at 13 dpi. Silicon treatment resulted in a significant reduction of disease severity after 10 dpi (Fig. 2). The disease index was reduced $31.6 \%$ as compared with Si-deprived plants at 13 dpi. In the cultivar Gynlim, the disease development was delayed and the disease index was much lower than that in the susceptible cultivar UC157. Meanwhile, the final disease index was reduced by $14 \%$ when amended with $\mathrm{Si}$ at 13 dpi compared with the control.

Silicon concentration. The supply of $\mathrm{Si}$ markedly increased the Si concentration in asparagus plants and was significantly higher in asparagus roots compared with shoot tissue in all Si-treated plants (Table 1). In noninoculated plants, the $\mathrm{Si}$ concentration increased 6.3-fold in Si-treated roots and 1.6-fold in shoots for the cultivar UC157, whereas 7.7- and 3.3-fold in the roots and shoots, respectively, for the cultivar Gynlim. Inoculation with $P$. asparagi significantly $(P=0.013)$ increased $\mathrm{Si}$ concentrations in the shoots $(+40.4 \%)$, but not in the roots for 'UC157'.

The activities of antioxidant enzymes in asparagus cultivar UC157. CAT activity clearly increased with time in all treatments (Fig. 3). Without inoculation, the time-course change for CAT activities in Si-treated plants was similar to control plants. The inoculation significantly increased CAT activity in asparagus plants compared with noninoculated treatment. Interestingly, CAT activity was higher in the inoculated Si-treated plants than in Si-deprived plants and increased $29.2 \%$ at 13 dpi. The interaction between Si treatment and inoculation was also significant $(P=$ 0.019 at $13 \mathrm{dpi}$ ) (Table 2).

After inoculation, SOD activity in Sitreated plants showed a transient increase at an early stage (1 dpi) compared with the Sideprived plants (Fig. 3). Furthermore, SOD activities in inoculated plants increased sharply and became significantly higher than those in noninoculated plants at $4 \mathrm{dpi}$ and then decreased markedly after $7 \mathrm{dpi}$.

POD activity increased with time for all treatments, but reached the highest level at 10 dpi in inoculated plants and then decreased thereafter. Inoculation with $P$. asparagi significantly $(P=0.0007)$ increased POD activity after $7 \mathrm{dpi}$, and Si treatment also significantly $(P=0.0389)$ increased the POD activity in inoculated or noninoculated plants (Fig. 3).

Inoculation with $P$. asparagi could significantly increase DHAR activity at $7 \mathrm{dpi}$ and thereafter (Fig. 3). DHAR activities in Sisupplied plants were slightly higher than in Si-deprived plants after 7 dpi in noninoculated plants. In addition, Si plus inoculation
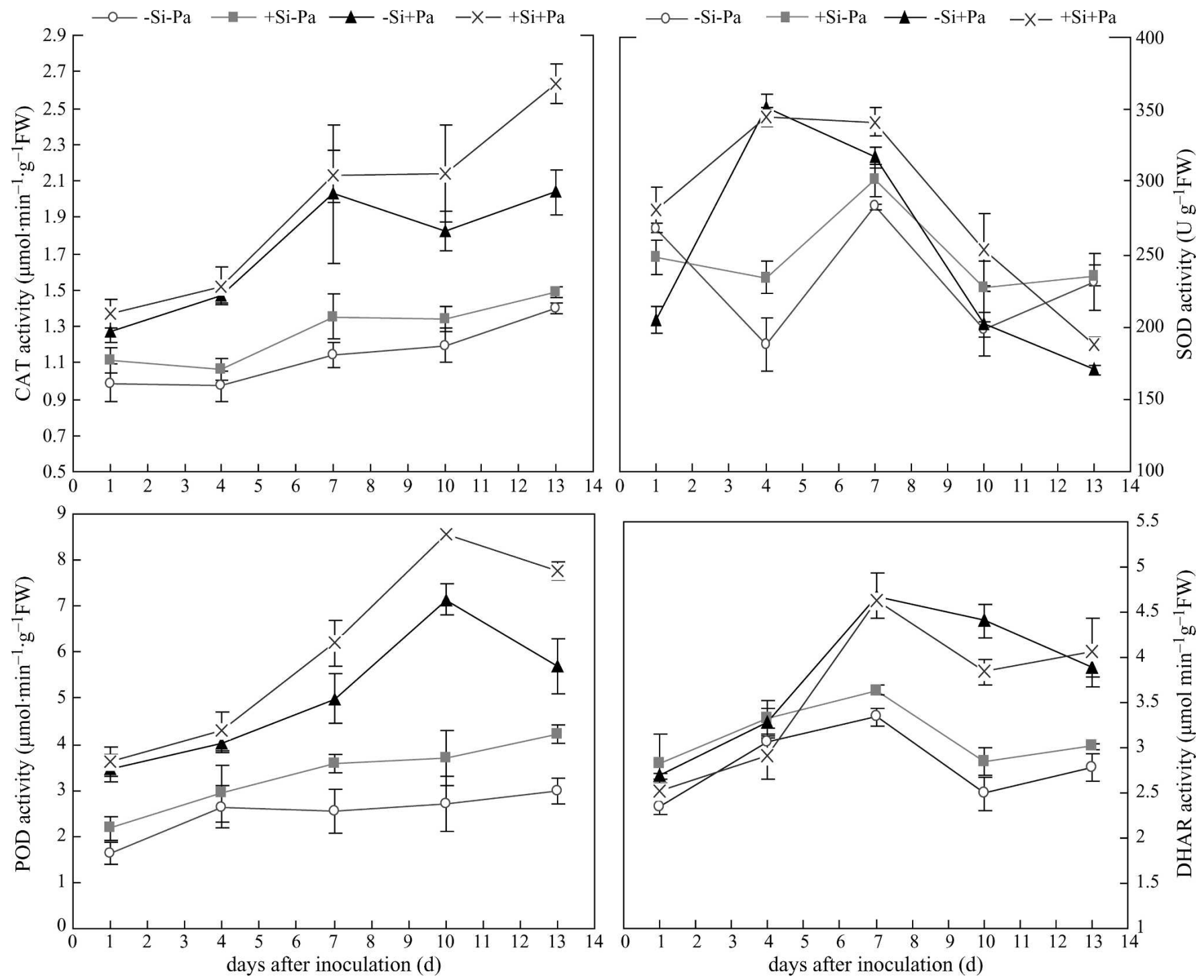

Fig. 3. Effect of silicon and Phomopsis asparagi on the activities of catalase (CAT), superoxide dismutase (SOD), peroxidase (POD), and dehydroascorbate reductase (DHAR) in asparagus plants. Data points represent means of three repeated trials \pm SE. 
did not enhance DHAR activity when compared with the non-Si-inoculated plants (Table 2).

Changes in polyphenoloxidases and phenylalanine ammonialyase activities. PPO and PAL activities increased with time in all treatments except PAL accumulation decreased slightly after $10 \mathrm{dpi}$ for inoculated plants (Fig. 4). Inoculation significantly increased PPO and PAL activity (Table 2). In addition, $\mathrm{Si}$ significantly $(P=0.0069)$ increased PAL activity after 7 dpi whether or not the plant was inoculated. Si treatment led to an increase of PPO activity by $21.8 \%$ at 13 dpi in inoculated plants, when tissue necrosis became apparent. However, in noninoculated plants, the effect of Si on PPO activity was not significant as compared with untreated plants.

The activity of $\beta$-1, 3-glucanase and chitinase. Inoculation with $P$. asparagi significantly enhanced the $\beta$-1, 3-glucanase activity in asparagus plants without and with $\mathrm{Si}$ (Fig. 5). In noninoculated plants, $\mathrm{Si}$ enhanced $\beta$-1, 3-glucanase activity over the control. No significant differences were detected in enzyme activity between $-\mathrm{Si}+\mathrm{Pa}$ and $+\mathrm{Si}+\mathrm{Pa}$.

The effects of $P$. asparagi on chitinase activities were very similar to those for $\beta-1$, 3 -glucanase in asparagus (Fig. 5). Inoculation with $P$. asparagi significantly enhanced the chitinase activities, but Si had no influence on this activity (Table 2).

\section{Discussion}

In our present study, the addition of $\mathrm{Na}_{2} \mathrm{SiO}_{3}$ to the media markedly inhibited the fungal growth of $P$. asparagi, whereas $\mathrm{NaCl}$ had no significant effect. These results suggest that soluble Si might directly inhibit mycelial growth, and the reduction was not the result of either $\mathrm{Na}$ ion or an osmotic effect. In addition, the continuous feeding of $\mathrm{Si}$ to hydroponic-grown asparagus significantly decreased stem blight symptom development in the susceptible genotype 'UC157' and in the partially resistant genotype 'Gylim'. Si-treated plants showed significantly lower disease indices than Si-deprived plants. As such, Si significantly improved the resistance to stem blight development in asparagus.

Silicon content in root and stem increased markedly when supplied with $1.5 \mathrm{mmol} \cdot \mathrm{L}^{-1}$ $\mathrm{Na}_{2} \mathrm{SiO}_{3}$ regardless whether the plant was inoculated with $P$. asparagi. No significant differences were detected in Si content of the root or shoot whether or not the plant was inoculated for the cultivar Gynlim. Only in the susceptible cultivar, UC157, did inoculation significantly increase the Si content in asparagus shoots. So it was suggested that, although $\mathrm{Si}$ accumulated in asparagus roots, Si might induce resistance in shoots in susceptible genotypes. Dann and Muir (2002) proved peas grown in $\mathrm{Si}$-amended media accumulated more foliar Si and fewer lesions developed on inoculated stems. Also, Diogo and Wydra (2007) suggested Si triggered

Table 2. Statistical analyses of the variables of enzyme activity at 13 dpi.

\begin{tabular}{lcccccccc}
\hline Source of & \multicolumn{7}{c}{ Variables } \\
\cline { 2 - 9 } variation & CAT & SOD & POD & DHAR & PPO & PAL & $\beta$-1,3-glucanase & Chitinase \\
\hline Si & 0.0109 & NS & 0.0017 & NS & 0.0091 & 0.0001 & NS & NS \\
Inoculation & $<0.0001$ & 0.0144 & $<0.0001$ & $<0.0001$ & $<0.0001$ & $<0.0001$ & 0.0409 & 0.0283
\end{tabular}

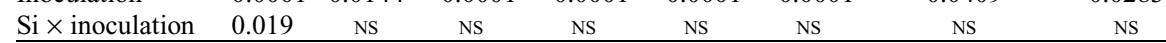

The data refer to the $P$ value based on two-way analysis of variance (ANOVA).

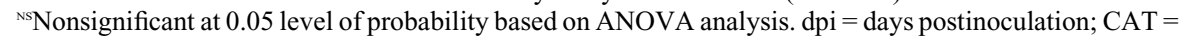
catalase; $\mathrm{SOD}=$ superoxide dismutase; $\mathrm{POD}=$ peroxidase; $\mathrm{DHAR}=$ dehydroascorbate reductase; $\mathrm{PPO}=$ polyphenoloxidases; $\mathrm{PAL}=$ phenylalanine ammonialyase; $\mathrm{Si}=$ silicon.
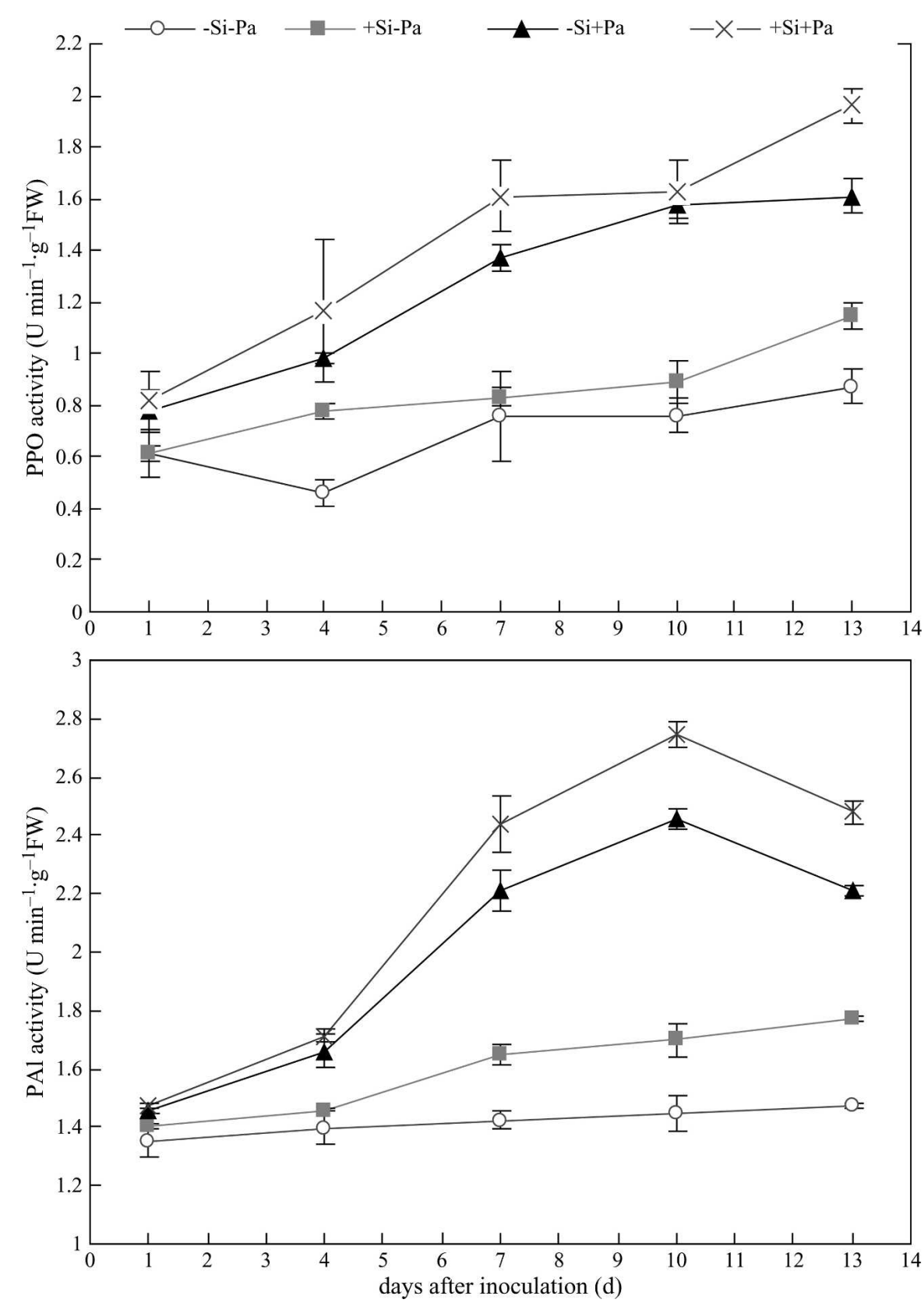

Fig. 4. Effect of silicon and Phomopsis asparagi on polyphenoloxidases (PPO) and phenylalanine ammonialyase (PAL) activity in asparagus plants. Data points represent means of three repeated trials \pm SES.

important mechanisms of resistance to bacterium wilt located in tomato stem.

Membrane lipid peroxidation is thought to be one of the most important mechanisms of stress reaction in higher plants (Fadzilla et al., 1997). CAT, SOD, and POD are the major antioxidant enzymes associated with scavenging the active oxygen species (AOS) (Milosevic and Slusarenko, 1996). The oxidative burst orchestrates the plant hypersensitive disease resistance. The increases in the activities of antioxidant enzymes, including 

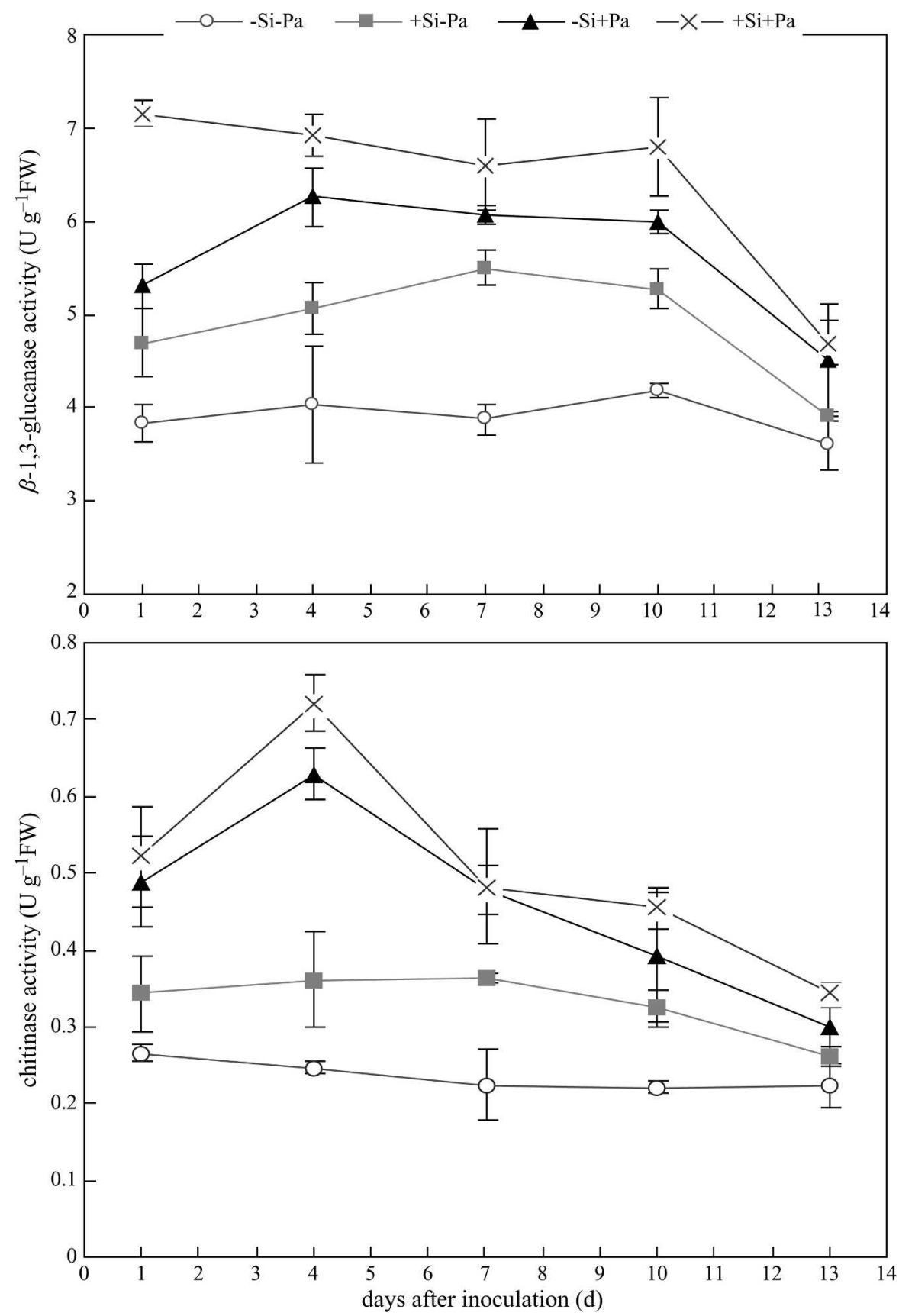

Fig. 5. Effect of silicon and Phomopsis asparagi on chitinase and $\beta$-1, 3-glucanase activities in asparagus plants. Data points represent means of three repeated trials \pm SE.

SOD, CAT, APX, GPX, and DHAR were responsible for the enhanced capability for elimination of AOS and inhibited further disease development (Lamb and Dixon, 1997). In the present study, the supply of Si increased CAT, SOD, and POD activities in asparagus when inoculated with $P$. asparagi, suggesting that Si may affect the structure, integrity, and functions of plasma membranes by influencing the peroxidation of membrane lipids. Noninoculated plants exhibited no significant difference in the activities of these antioxidant enzymes either with or without Si. Similar results were reported in cucumber (Shi et al., 2005) and wheat (Liang et al., 2007). The alleviation of drought and salt stresses by $\mathrm{Si}$ had been related to its effect on antioxidant enzyme activity (Gong et al., 2005; Liang et al., 2003). However, there is little information available about the possible beneficial effects of $\mathrm{Si}$ on the antioxidative system in the performance of inducing disease resistance. In the present study, we proved Si-alleviated effects on fungal diseases were also associated with the antioxidant defense abilities. Antioxidative systems may be one of the factors determining the Si-treated effect on the response to pathogen attack.

The activities of PAL and PPO were enhanced by inoculation. Meanwhile, Si also increased the activities of PAL and PPO in the inoculated plants. It was assumed that $\mathrm{Si}$ helped stimulate accumulation of polymer- ized phenolics by stimulating the activities of PAL, PPO, and POD (Chérif et al., 1992). The increased activities in POD and PAL have been thought to be key components in local and systemic disease resistance (Kombrink and Somssich, 1995). PAL activity is associated with biosynthesis of toxic metabolites such as phytoalexins, phenols, lignins, and salicylic acid in plant defense pathways (Liu and Rahe, 1997; Mauch-Mani and Slusarenko, 1996). So Si was suggested to play an important role in phenolic metabolism and in the biosynthesis of lignin in cell walls (Marschner, 1995). Silicon also has been associated with enhanced ability to produce phenolic phytoalexins and defense associated enzymes in cucumber (Fawe et al., 1998), wheat (Rémus-Borel et al., 2005), and rice (Rodrigues et al., 2004, 2005), in which the activity of PR proteins and phytoalexins are increased. In the present study, soluble $\mathrm{Si}$ enhanced the activities $\beta$-1, 3-glucanase and chitinase, which also suggested that the role of soluble $\mathrm{Si}$ in asparagus-pathogen interactions through root uptake of Si appeared to be active, presumably as a signal for inducing defense reactions, and this Si-enhanced resistance was mediated through an unknown mechanism, whereas increased activity of PRs was consequently produced (Dann and Muir, 2002). The regulation of plant defense genes by Si may be useful for enhanced resistance to plant disease (Chérif et al., 1992; Rodrigues et al., 2005). Rodrigues et al. (2005) proved PR-11 accumulation appeared to be more intense in Si-treated plants than untreated plants, consequently stimulating the host defense mechanisms to fungus pathogens.

The results suggest that supplementing $\mathrm{Si}$ in the solution culture would increase the accumulation of $\mathrm{Si}$ within asparagus plants and activate early host defense against stem blight while subsequently improving resistance to fungal pathogens. As such, Si might play a role as an inducer of disease resistance, which was based on the systemic activation of natural plant defense mechanisms. To our knowledge, this is the first report demonstrating suppressive effects of soluble $\mathrm{Si}$ against fungal disease in asparagus. Future studies should examine the mechanism behind this suppressive effect of soluble Si to develop an integrated method to control stem blight in asparagus.

\section{Literature Cited}

Bélanger, R.R., N. Benhamou, and J.G. Menzies. 2003. Cytological evidence of an active role of $\mathrm{Si}$ in wheat resistance to powdery mildew (Blumeria graminis f. sp. tritici). Phytopathol. 93:402-412.

Boller, T. and J.P. Metraux. 1988. Colorimetric assay for chitinase. Methods Enzymol. 161: 430-435.

Bowen, P., J. Menzies, and D. Ehret. 1992. Soluble Si sprays inhibit powdery mildew development on grape leaves. J. Amer. Soc. Hort. Sci. 117:906-912.

Cakmak, I. and H. Marschner. 1992. Magnesium deficiency and high light intensity enhance activities of superoxide dismutase, ascorbate 
peroxidase, and glutathione reductase in bean leaves. Plant Physiol. 98:1222-1227.

Carver, T.L.W., R.J. Zeyen, and G.G. Ahlstand. 1987. The relationship between insoluble $\mathrm{Si}$ and success or failure of attempted primary penetration by powdery mildew (Elysiphe graminis) germlings of barley. Physiol. Mol. Plant Pathol. 31:133-148.

Chérif, M., A. Asselin, and R.R. Belanger. 1994. Defense responses induced by soluble cucumber roots infected by Pythium spp. Phytopathol 84:236-242.

Chérif, M., N. Benhamou, J.G. Menzies, and R.R. Belanger. 1992. Si induced resistance in cucumber plants against Pythium ultimum. Physiol. Mol. Plant Pathol. 41:411-425.

Dann, E.K. and S. Muir. 2002. Peas grown in media with elevated plant-available silicon levels have higher activities of chitinase and b-1,3glucanase, are less susceptible to a fungal leaf spot pathogen and accumulate more foliar silicon. Australas. Plant Pathol. 31:9-13.

Davis, R.D. 2001. Asparagus stem blight recorded in Australia. Australas. Plant Pathol. 30:181182.

Diogo, R. and K. Wydra. 2007. Silicon-induced basal resistance in tomato against Ralstonia solanacearum is related to modification of pectic cell wall polysaccharide structure. Physiol. Mol. Plant Pathol. 70:120-129.

Elena, K. 2006. First report of Phomopsis asparagi causing stem blight of asparagus in Greece. Plant Pathol. 55:300.

El-Ghaouth, A., J. Arul, J. Grenier, and A. Asselin. 1992. Antifungal activity of chitosan on two post-harvest pathogens of strawberry fruits. Phytopathol. 82:398-402.

Epstein, E. 1994. The anomaly of silicon in plant biology. Proc. Natl. Acad. Sci. USA 91:11-17.

Fadzilla, N.M., R.P. Finch, and R.H. Burdon. 1997. Salinity, oxidative stress and antioxidant responses in shoot culture of rice. J. Expt. Bot. 48:325-331.

FAO statistical database. 2008. Rome. 24 Mar. $2008<$ http:faostat.fao.org/default.aspx $>$.

Fauteux, F., W. Rémus-Borel, J.G. Menzies, R. Richard, and R.R. Bélanger. 2005. Silicon and plant disease resistance against pathogenic fungi. FEMS Microbiol. Lett. 249:1-6.

Fawe, A., M. Abou-Zaid, J.G. Menzies, and R.R. Bélanger. 1998. Silicon-mediated accumulation of flavonoid phytoalexins in cucumber. Phytopath. 88:396-401.

Giannopolitis, C.N. and S.K. Ries. 1977. Superoxide dismutase. I. Occurrence in higher plants. Plant Physiol. 59:309-314.

Gong, H., X. Zhu, K. Chen, S. Wang, and C. Zhang. 2005. Silicon alleviates oxidative damage of wheat plants in pots under drought. Plant Sci. 169:313-321

Kanto, T., A. Miyoshi, T. Ogawa, K. Maekawa, and M. Aino. 2006. Suppressive effect of liquid potassium silicate on powdery mildew of strawberry in soil. J. Gen. Plant Pathol. 72: 137-142.

Kawashima, R. 1927. Effect of silicate against rice blast. Soil Sci. Plant Nutr. 1:86-91.

Kombrink, E. and I.E. Somssich. 1995. Defence responses of plants to pathogens. Adv. Bot. Res. 21:1-34.

Lamb, C. and R.A. Dixon. 1997. The oxidative burst in plant disease resistance. Ann. Rev. Plant Physiol. Plant Molec. Biol. 48:251-275.

Liang, Y., Q. Chen, Q. Liu, W. Zhang, and R. Ding. 2003. Exogenous silicon (Si) increases antioxidant enzyme activity and reduces lipid peroxidation in roots of salt-stressed barley (Hordeum vulgare L.). J. Plant Physiol. 160:1157-1164.

Liang, Y.C., W.C. Sun, Y.G. Zhu, and P. Christie. 2007. Mechanisms of silicon-mediated alleviation of abiotic stresses in higher plants: A review. Environ. Pollut. 147:422-428.

Liu, L. and J.E. Rahe. 1997. Altered root exudation and suppression of induced lignification as mechanisms of predisposition by glyphosate of bean roots (Phaseolus vulgaris L.) to colonization by Pythium spp. Physiol. Mol. Plant Pathol. 51:111-127.

Lu, G. 2001. Comparison of three methods for determination of $\mathrm{Si}$ content in horticultural crops. J. Zhejiang Univ. 27:518-522.

Ma, J.F. 2004. Role of silicon in enhancing the resistance of plants to biotic and abiotic stresses. Soil Sci. Plant Nutr. 50:11-18.

Ma, J.F. and N. Yamaji. 2006. Silicon uptake and accumulation in higher plants. Trends Plant Sci. 41:136-138.

Marschner, A. 1995. Mineral nutrition of higher plants. Academic Press, San Diego, CA.

Mauch-Mani, B. and A.J. Slusarenko. 1996. Production of salicylic acid precursors is a major function of phenylalanine ammonia-lyase in the resistance of Arabidopsis to Peronospora parasitica. Plant Cell 8:203-212.

Milosevic, N. and A.J. Slusarenko. 1996. Active oxygen metabolism and lignification in the hypersensitive response in bean. Physiol. Mol. Plant Pathol. 49:143-158.

Nakano, Y. and K. Asada. 1981. Hydrogen peroxide is scavenged by ascorbate-specific peroxidase in spinach chloroplasts. Plant Cell Physiol. 22:67-88.

Reifschneider, F.J.B. and C.A. Lopes. 1982. Phoma asparagi on asparagus. FAO Plant Protection Bulletin 30:157.
Rémus-Borel, W., J.G. Menzies, and R.R. Belanger. 2005. Silicon induces antifungal compounds in powdery mildew-infected wheat. Physiol. Mol. Plant Pathol. 66:108-115.

Rivas, N.J. and J.R. Whitaker. 1973. Purification and some properties of two polyphenol oxidase from Bartlett pears. Plant Physiol. 52:501-507.

Rodrigues, F.A., N. Benhamou, L.E. Datnoff, J.B. Jones, and R.R. Belanger. 2003. Ultrastructural and cytochemical aspects of silicon-mediated rice blast resistance. Phytopathol. 93:535546.

Rodrigues, F.Á., L.E. Datnoff, G.H. Korndörfer, K.W. Seebold, and M.C. Rush. 2001. Effect of silicon and host resistance on sheath blight development in rice. Plant Dis. 85:827-832.

Rodrigues, F.Á., W.M. Jurick, L.E. Datnoff, J.B. Jones, and J.A. Rollins. 2005. Silicon influences cytological and molecular events in compatible rice-Magnaporthe grisea interactions. Physiol. Mol. Plant Pathol. 66:144-159.

Rodrigues, F.Á., D.J. McNally, L.E. Datnoff, J.B. Jones, C. Labbe, N. Enhamou, J.G. Menzies, and R.R. Bélanger. 2004. Silicon enhances the accumulation of diterpenoid phytoalexins in rice: A potential mechanism for blast resistance. Phytopathol. 94:177-183.

Samuels, A.L., A.D.M. Glass, D.L. Ehret, and J.G. Menzies. 1993. The effect of silicon supplementation on cucumber fruit: Changes in surface characteristics. Ann. Bot. (Lond.) 72: 433-440.

SAS Institute. 2002. SAS/STAT user's guide, version 8.2. SAS Institute, Cary, NC.

Shi, Q.H., Z.Y. Bao, and Z.J. Zhu. 2005. Siliconmediated alleviation of Mn toxicity in Cucumis sativus in relation to activities of superoxide dismutase and ascorbate peroxidase. Phytochem. 66:1551-1559.

Sonoda, T., A. Uragami, and K. Kaji. 1997. Evaluation of Asparagus officinalis cultivars for resistance to stem blight by using a novel inoculation method. HortScience 32:10851086

Taber, H.G., D. Shogren, and G. Lu. 2002. Extraction of silicon from plant tissue with dilute $\mathrm{HCI}$ and HF and measurement by modified inductive coupled argon plasma procedures. Commun. Soil Sci. Plant Anal. 33:16611670 .

Uecker, F.A. and D.A. Johnson. 1991. Morphology and taxonomy of species of Phomopsis on Asparagus. Mycologia 83:192-199.

Zhu, Z.J., J.Q. Yu, J. Gerendas, and B. Sattelmacher. 1998. Effect of light intensity and nitrogen form on growth and activities of $\mathrm{H}_{2} \mathrm{O}_{2}$-scavenging enzymes in tobacco. Plant Nutr. Fertil. Sci. 4:379-385. 